\title{
Fluorescein Diacetate Activity as Affected by Residue Retention and P Fertilization in Maize under Maize-Wheat Cropping System
}

\author{
Chiranjeev Kumawat, V.K. Sharma*, M.C. Meena, Sarvendra Kumar, \\ Mandira Barman, Kapil A. Chobhe and R.K. Yadav
Division of Soil Science and Agricultural Chemistry, ICAR-Indian Agricultural Research Institute, New Delhi-110 012, India
*Corresponding author

\begin{tabular}{|c|c|}
\hline & A B S T R A C T \\
\hline $\begin{array}{l}\text { Ke y w or d s } \\
\text { Crop residue, } \\
\text { Microbial } \\
\text { inoculants, } \\
\text { Enzyme } \\
\text { activity }\end{array}$ & \multirow{3}{*}{$\begin{array}{l}\text { Crop residue (CR) retention is one of the viable option for improving soil } \\
\text { properties as well as soil microbial community. Different enzymatic activity in } \\
\text { soil is used as indicator of soil biological health. Experiment was conducted to } \\
\text { access the crop residue retention and P fertilization on fluorescein diacetate } \\
\text { activity (FDA) in soil which is an important indicator of microbial activity vis-a- } \\
\text { vis biological health of soil. Maize-wheat cropping system is the third most } \\
\text { important cropping system after rice-wheat and rice-rice cropping system in India. } \\
\text { Crop residue retention @ } 50 \% \text { and } 75 \% \text { significantly enhanced fluorescein } \\
\text { diacetate activity of soil, irrespective of soil sampling zone and depth. FDA in soil } \\
\text { was significantly higher in rhizospheric soil than the non-rhizospheric soil. Both in } \\
\text { rhizospheric and non rhizospheric soil }(0-5 \mathrm{~cm}) \text {, FDA had significant and positive } \\
\text { relation with P fertilization. }\end{array}$} \\
\hline Article Info & \\
\hline $\begin{array}{l}\text { Accepted: } \\
\text { 25 April } 2017 \\
\text { Available Online: } \\
10 \text { May } 2017\end{array}$ & \\
\hline
\end{tabular}

\section{Introduction}

Tillage and residue retention management affect soil properties and also soil microbial community. Soil microorganisms play important roles in agro ecosystem, and their changes influences soil nutrient cycling. Notillage with residue retention is known to increase the soil microbial community (Govaerts et al., 2007). Application of decomposed residues in form of farm yard manure play a vital role in exploiting high yield potential through its beneficial effect on nutrients supply and chemical and biological properties (Sharma et al., 2015 and 2016).
On the other hand mulching effect of residue retention improves the physical condition and fertility of the soil. It also check runoff and soil erosion, increase infiltration, help to maiintain proper soil temperature, inhibit movement of water vapour (evaporation) from soil to air, check weed growth and thereby, cut transpiration loss of water, and reduce soil compaction and aggregate breakdown (Mbagwu, 1991, Ghosh et al., 2006). Enzymes are vital soil components involved in the dynamics of soil nutrient transformations. Enzyme activity in the soil milieu is considered to be a chief contributor 
of overall soil microbial activity (Frankenberger and Dick, 1983). The biomass of microbes and activities of different enzymes is typically thought to be regulating indicator of nutrient availability, resistance and resilience capacity of soil (Demoling et al., 2007; Kumar et al., 2014). Soil respiration and enzyme activities, particularly hydrolase activities, involved in organic matter turnover, hence in nutrient cycles and plant nutrition, have been utilized by soil scientists in order to investigate the effects of different soil management strategies and agricultural practices, including organic amendments on soil fertility and health (Dick, 1997). In this respect, soil FDA is an important indicator of soil microbial activity and biological health of soil. The aim of this research was to assess the effects of crop residue retention and $\mathrm{P}$ fertilization on FDA activity in soil.

\section{Materials and Methods}

\section{General information about experimental site}

An ongoing field experiment on conservation agriculture initiated during kharif 2013 at IARI Research Farm was chosen for further study. The experimental soil represents Indogangatic plain and Mahrauli series of order Inceptisol. Taxonomically it is classified as Typic Haplustept. The soil is alluvial, sandy loam in texture with low CEC, alkaline in reaction, free from salinity and has nearly level to gently sloping topography. The initial physico-chemical characteristics of the surface soil $(0-15 \mathrm{~cm})$ are given in Table 1 .

\section{Experimental details}

The field experiment on maize (Zea mays L.) -wheat (Triticum aestivum L.) cropping system commenced in July 2013 at IARI Research Farm. Twenty treatments were evaluated in a split-plot design, comprising crop residue retention (four) as main plot i.e.T1: Residue removal (No-residue), T2: 25\% crop residue, T3: $50 \%$ crop residue, T4: $75 \%$ crop residue and phosphorus fertilizer rate (five) in sub-plot treatments were S1: NoPhosphorus, S2: 50\% Recommended dose of phosphorus (RDP), S3: 100\% RDP, S4:150\% RDP, S5: 50\% RDP + PSB \& AM with three replications.

Soil test-based recommended N-P2O5-K2O rates were $150-80-50 \mathrm{~kg}$ ha-1 for maize, which were applied through urea, diammonium phosphate (DAP) and muriate of potash (MOP), respectively. Fertilizer $\mathrm{N}$ and $\mathrm{K}$ were applied uniformly to all the plots, whereas $\mathrm{P}$ was applied as per treatments. Entire amount of $\mathrm{P}$ and $\mathrm{K}$ was applied as basal dressing at the time of sowing. On the other hand, $\mathrm{N}$ was applied in 3 equal splits i.e. at sowing, at four leaves vegetative stage and eight leaves vegetative stage of maize. Previous wheat crop residues were retained in plots. Maize (cv. PHM-1) was sown in first week of July and harvested during end of October. Previous wheat crop was harvested manually from ground level, and aboveground biomass/residues were retained in the plots. Maize crop was raised under assured irrigated condition, and prescribed weed and pest control measures were adopted.

\section{Soil sampling and processing}

Plot-wise soil samples were collected at tasseling stage for determination of enzymatic activities from rhizospheric and non rhizospheric soil $(0-5 \mathrm{~cm}$ and $5-15 \mathrm{~cm})$. For this, plants were uprooted with intact roots and adhering soil was removed by gently shaking the roots on a clean plastic sheet. Soil beneath the root up to a depth of $15 \mathrm{~cm}$ from top was also collected and mixed with the adhered soil. The samples were separated into two parts; one part was processed for chemical analysis and the other part was 
preserved in refrigerator at $4 \mathrm{oC}$ for enzymatic analysis. The samples for chemical analysis were dried in shade, ground in wooden pestlemortar, and sieved to pass through a $2 \mathrm{~mm}$ sieve. All the chemical analysis of soil samples were done according to the methods outlined by Page et al., (1982). Fluorescein diacetate hydrolysis was estimated as per the method outlined by Green et al., (2006). The activity was estimated through the production of fluorescein from fluorescein diacetate by the action of hydrolytic enzymes in soil. In brief, one gram of soil was taken in a screw cap vial and $5.0 \mathrm{~mL}$ of $60 \mathrm{mM}$ sodium phosphate $(\mathrm{pH} 7.6)$ and $10 \mu \mathrm{l}$ of fluorescein diacetate $(0.02 \%)$ were added. The tubes were incubated at $37^{\circ} \mathrm{C}$ for $3 \mathrm{~h}$. The reaction was stopped by adding $0.2 \mathrm{~mL}$ of acetone after incubation period i.e. 3 hrs. The mixture was centrifuged at $8000 \mathrm{rpm}$ for 5 minute, further filtered through Whatman No. 2 filter paper and absorbance was recorded spectrophotometrically at $490 \mathrm{~nm}$.

\section{Results and Discussion}

\section{Effect of $\mathrm{CR}$ and $P$ fertilization on Fluroscence Diacetate Activity (FDA)}

Fluroscence diacetate activity in soil as affected by different amount of crop residue retention and doses of $\mathrm{P}$ fertilizer in rhizospheric soil are presented in (Table 2). Highest FDA (378.3 $\mu \mathrm{g}$ fluorescein g-1 dry soil h-1) was recorded with $75 \%$ CR, while lowest FDA (349.6 $\mu \mathrm{g}$ fluorescein g-1 dry soil h-1) in $25 \%$ CR. Significant increase in FDA was recorded at $50 \% \mathrm{CR}$ and $75 \% \mathrm{CR}$ over control. But these two treatments were equally effective in increasing the FDA activity in soil. In case of $P$ fertilization, application of higher dose improved FDA activity. Highest FDA (398.4 $\mu \mathrm{g}$ fluorescein g-1 dry soil h-1) was recorded with $100 \%$ RDP, followed by P fertilization @ 50\% RDP + PSB \& AM (386.1 $\mu \mathrm{g}$ fluorescein g-1 dry soil h-1) and lowest (340.5 $\mu \mathrm{g}$ fluorescein g-1 dry soil h-1) in 50\% RDP. Treatments $100 \%$ RDP and 50\% RDP + PSB \& AM were statistically at par with each other and significantly higher than rest of the treatments with respect to FDA of rhizospheric. Interactive effect of $\mathrm{CR}$ and $\mathrm{P}$ fertilization was no significant on FDA activity.

Fluroscence diacetate activity in non rhizospheric soil as evident in $(0-5 \mathrm{~cm})$ Table 3, are maximum FDA (298 fluorescein g-1 dry soil h-1) in $75 \%$ CR followed by $50 \%$ CR (294 fluorescein g-1 dry soil h-1) and minimum (260 fluorescein g-1 dry soil h-1) in No CR. Significant increase in FDA was observed with $75 \%$ CR over the control. Treatments $50 \% \mathrm{CR}$ and $75 \% \mathrm{CR}$ were statistically at par and significantly higher over $25 \%$ CR treatment. Application of $100 \%$ RDP recorded significantly higher FDA (302 $\mu \mathrm{g}$ fluorescein gm-1 dry soil h-1) over other treatments. Both the treatments 50\% RDP and $150 \%$ RDP were statistically at par with each other.

Crop residue retentions had no significant effect on FDA Fluroscence diacetate activity (FDA) in 5-15 cm soil depth (Table 4). FDA activity increases with increasing rate of $\mathrm{P}$ fertilizer up to $100 \%$ RDP over control. Maximum FDA (197 fluorescein g-1 dry soil h-1) was observed with $100 \%$ RDP treatment, followed by $150 \%$ RDP (184 fluorescein g-1 dry soil h-1) and minimum (172 fluorescein g-1 dry soil h-1) in No P (control). Exceptionally, 100\% RDP treatment recorded very high FDA activity than rest of the treatments. Thus both in rhizospheric and non rhizospheric soil $(0-5 \mathrm{~cm})$, FDA had significant and positive relation with $\mathrm{CR}$ and $\mathrm{P}$ fertilization. But this activity was higher in rhizospheric soil than non rhizospheric soil. This may be attributed to the fact that, the oxidative functional activity of microbial communities in the rhizosphere is higher than 
that of bulk soil. Yang et al (2013). This higher oxidative functional activity may be due to the higher carbon resources in the rhizosphere soil, which is considered as the driving force for microbial activity and density as reported by several workers (Bowen and Rovira, 1999; Yang et al., 2013).

Table.1 Initial soil characteristics of the field experiment

\begin{tabular}{ll}
\hline Parameter & Value \\
\hline pH & 8.53 \\
EC & 0.45 \\
Mechanical Composition & Sandy loam \\
Clay (\%) & 18 \\
Silt (\%) & 23.8 \\
Sand (\%) & 58.2 \\
Texture & Sandy loam \\
Organic Carbon (\%) & 0.32 \\
Available N $\left(\mathrm{kg} \mathrm{ha}^{-1}\right)$ & 189 \\
Available P $\left(\mathrm{kg} \mathrm{ha}^{-1}\right)$ & 26.1 \\
Available K $\left(\mathrm{kg} \mathrm{ha}^{-1}\right)$ & 227 \\
DTPA-Zn $\left(\mathrm{mg} \mathrm{kg}^{-1}\right)$ & 3.2 \\
DTPA-Fe $\left(\mathrm{mg} \mathrm{kg}^{-1}\right)$ & 5.6 \\
DTPA-Cu $\left(\mathrm{mg} \mathrm{kg}^{-1}\right)$ & 2.8 \\
DTPA-Mn $\left(\mathrm{mg} \mathrm{kg}^{-1}\right)$ & 7.1 \\
\hline
\end{tabular}

*USDA-United States Department of Agriculture

Table.2 Fluorescence diacetate activity ( $\mu$ g fluorescein $\mathrm{g}^{-1}$ soil $\mathrm{h}^{-1}$ ) in rhizospheric soil as affected by crop residues and phosphorus fertilization

\begin{tabular}{|c|c|c|c|c|c|c|}
\hline \multirow[b]{2}{*}{$\begin{array}{l}\text { Crop } \\
\text { residue } \\
(\mathbf{C R})\end{array}$} & \multicolumn{6}{|c|}{ Phosphorus rates $(\mathrm{P})$} \\
\hline & No-P & $\begin{array}{l}50 \% \\
\text { RDP }\end{array}$ & $\begin{array}{l}100 \% \\
\text { RDP }\end{array}$ & $\begin{array}{l}150 \% \\
\text { RDP }\end{array}$ & $\begin{array}{l}50 \% \text { RDP } \\
+ \text { PSB \& } \\
\text { AM }\end{array}$ & Mean \\
\hline No-CR & 325 & 326 & 392 & 338 & 368 & $350^{B}$ \\
\hline $25 \% \mathrm{CR}$ & 331 & 343 & 382 & 327 & 363 & $349^{B}$ \\
\hline $50 \% \mathrm{CR}$ & 356 & 344 & 405 & 359 & 403 & $373^{A}$ \\
\hline $75 \% \mathrm{CR}$ & 356 & 348 & 413 & 363 & 409 & $378^{A}$ \\
\hline Mean & $342^{B}$ & $340^{B}$ & $398^{\mathrm{A}}$ & $347^{B}$ & $386^{\mathrm{A}}$ & \\
\hline & CR & $\mathrm{P}$ & $\mathrm{P}$ at sa & & CR at same & \\
\hline $\operatorname{SEm}( \pm)$ & 8.42 & 8.25 & 16.50 & & 17.00 & \\
\hline $\begin{array}{l}\text { LSD } \\
(p \leq 0.05)\end{array}$ & 20.61 & 16.81 & NS & & NS & \\
\hline
\end{tabular}


Table.3 Fluorescence diacetate activity ( $\mu \mathrm{g}$ fluorescein $\mathrm{g}^{-1}$ soil $\mathrm{h}^{-1}$ ) in $0-5 \mathrm{~cm}$ soil as affected by crop residues and phosphorus fertilization

\begin{tabular}{|c|c|c|c|c|c|c|}
\hline \multirow{2}{*}{$\begin{array}{l}\text { Crop residue } \\
\text { (CR) }\end{array}$} & \multicolumn{6}{|c|}{ Phosphorus rates (P) } \\
\hline & No-P & $\begin{array}{l}\text { 50\% } \\
\text { RDP }\end{array}$ & $\begin{array}{l}100 \% \\
\text { RDP }\end{array}$ & $\begin{array}{l}150 \% \\
\text { RDP }\end{array}$ & $\begin{array}{l}50 \% \text { RDP + } \\
\text { PSB \& AM }\end{array}$ & Mean \\
\hline No-CR & 251 & 257 & 270 & 262 & 261 & $260^{B}$ \\
\hline $25 \% \mathrm{CR}$ & 255 & 255 & 306 & 266 & 254 & $267^{B}$ \\
\hline $50 \% \mathrm{CR}$ & 269 & 322 & 314 & 258 & 306 & $294^{\mathrm{A}}$ \\
\hline $75 \% \mathrm{CR}$ & 322 & 259 & 317 & 277 & 315 & $298^{A}$ \\
\hline Mean & $274^{\mathrm{C}}$ & $273^{C D}$ & $302^{\mathrm{A}}$ & $266^{D}$ & $284^{B}$ & \\
\hline & $\mathrm{CR}$ & $\mathrm{P}$ & \multicolumn{2}{|c|}{$\mathrm{P}$ at same $\mathrm{CR}$} & \multicolumn{2}{|l|}{$\mathrm{CR}$ at same $\mathrm{P}$} \\
\hline $\operatorname{SEm}( \pm)$ & 4.11 & 4.09 & \multicolumn{2}{|l|}{8.18} & \multicolumn{2}{|l|}{8.39} \\
\hline $\begin{array}{l}\text { LSD } \\
0.05)\end{array}$ & 10.06 & 8.33 & \multicolumn{2}{|l|}{16.66} & \multicolumn{2}{|l|}{17.92} \\
\hline
\end{tabular}

Table.4 Fluorescence diacetate activity ( $\mu \mathrm{g}$ fluorescein $\mathrm{g}^{-1}$ soil $\mathrm{h}^{-1}$ ) in $5-15 \mathrm{~cm}$ soil as affected by crop residues and phosphorus fertilization

\begin{tabular}{|c|c|c|c|c|c|c|}
\hline \multirow{2}{*}{$\begin{array}{l}\text { Crop residue } \\
\text { (CR) }\end{array}$} & \multicolumn{6}{|c|}{ Phosphorus rates (P) } \\
\hline & No-P & 50\% RDP & $\begin{array}{l}100 \% \\
\text { RDP }\end{array}$ & $\begin{array}{l}150 \% \\
\text { RDP }\end{array}$ & $\begin{array}{l}50 \% \text { RDP + } \\
\text { PSB \& AM }\end{array}$ & Mean \\
\hline No-CR & 162 & 175 & 178 & 176 & 178 & 174 \\
\hline $25 \% \mathrm{CR}$ & 170 & 170 & 190 & 182 & 168 & 176 \\
\hline $50 \% \mathrm{CR}$ & 185 & 202 & 207 & 180 & 179 & 191 \\
\hline $75 \% \mathrm{CR}$ & 171 & 179 & 211 & 196 & 202 & 192 \\
\hline Mean & $172^{B}$ & $181^{B}$ & $197^{\mathrm{A}}$ & $184^{B}$ & $182^{B}$ & \\
\hline & $\mathrm{CR}$ & $\mathrm{P}$ & \multicolumn{2}{|c|}{$\mathrm{P}$ at same $\mathrm{CR}$} & \multicolumn{2}{|l|}{$\mathrm{CR}$ at same $\mathrm{P}$} \\
\hline $\operatorname{SEm}( \pm)$ & 6.91 & 6.42 & \multicolumn{2}{|l|}{12.84} & \multicolumn{2}{|l|}{13.40} \\
\hline $\operatorname{LSD}(p \leq 0.05)$ & NS & 13.08 & \multicolumn{2}{|l|}{ NS } & \multicolumn{2}{|l|}{ NS } \\
\hline
\end{tabular}


Similar results were reported by Lopes et al., (2010), where FDA hydrolysis activities were increased by native forest due to high deposition of residues. Other studies have also suggested that FDA activities are generally the most sensitive indicators of residue management changes on the belowground microbial community (Jordan et al., 1995). Conjoint application of CR with $50 \%$ $\mathrm{RDP}+\mathrm{PSM}$ and AM improved hydrolysis capacity of soil. Nath et al., (2011) found significant increase in FDA hydrolysis due to the combined use of compost and biofertilizers or enriched compost with substantial reduction of inorganic fertilizer. Singh and Dhar, 2011 reported a higher FDA due to integrated use of NPK and FYM which could be attributed to increased microbial biomass resulting from organic matter enrichment and enzymatic activities in soil. Activities of FDA which represent microbial activity of soil were increased with retention of crop residues than the control plot, in this study which is similar to some other studies (Huang et al., 2010). This might have been because there was more decomposable organic material in soil with the incorporated crop residues which favoured soil microbial population and activity.

In conclusion the crop residue retention @50\% and 75\% significantly enhanced fluorescein diacetate activity of soil, irrespective of soil sampling zone and depth. Thus both in rhizospheric and non rhizospheric soil $(0-5 \mathrm{~cm})$, FDA had significant and positive relation with $\mathrm{CR}$ and $\mathrm{P}$ fertilization. But this activity was higher in rhizospheric soil than non rhizospheric soil.

\section{References}

Bowen, G.D. and Rovira, A.D. 1999. The rhizosphere and its management to improve plant growth. Adv. Agron., 66: 1102.
Demoling, F., Figueroa, D. and Baath, E. 2007. Comparison of factors limiting bacterial growth in different soils. Soil Biol. Biochem., 39: 2485-2495.

Dick, R.P. 1997. Soil enzyme activities as integrative indicators of soil health. In: Pankhurst C, Doube BM, Gupta VVSR (eds. Biological indicators of soil health. CAB International, pp 121-156

Frankenberger, W. and Dick, W.A. 1983. Relationships between enzyme activities and microbial growth and activity indices in soil. Soil Sci. Society of America J., 47: 945-951.

Ghosh, P.K., Dayal, D., Bandyopadhay, K.K. and Mohanty, M. 2006. Evaluation of straw and polythene mulch for enhancing productivity of irrigated summer groundnut. Field Crops Res., 99: 76-86.

Govaerts, B., Fuentes, M., Mezzalama, M., Nicol, J. M., Deckers, J., Etchevers, J. D. and Sayre, K. D. 2007. Infiltration, soil moisture, root rot and nematode populations after 12 years of different tillage, residue and crop rotation managements. Soil and Tillage Res., 94: 209-219.

Green, V.S., Stott, D.E. and Diack, M. 2006. Assay for fluoresce in diacetate hydrolytic activity: optimization for soil samples. Soil Biol. Biochem., 38: 693701.

Huang, C., Deng, L.J., Gao, X.S., Zhang, S.R. and Luo, T. 2010. Effects of fungal residues return on soil enzymatic activities and fertility dynamics in a paddy soil under a rice-wheat rotation in Chengdu Plain. Soil and Tillage Res., 108: 16-23.

Jordan, D., Kremer, R.J., Bergfield, W.A., Kim, K.Y. and Cacnio, V.N. 1995. Evaluation of microbial methods as potential indicators of soil quality in historical agricultural fields. Biol. Fertility of Soils, 19: 297-302.

Kumar, S., Patra, A. K., Singh, D. and Purakayastha, T. J. 2014. Long term chemical fertilization along with farmyard manure enhances resistance and resilience 
of soil microbial activity against heat stress. J. Agron. Crop Sci., 200: 156-62.

Lopes, M.M., Salviano, A.A.C., Araujo, A. S. F., Nunes, L.A.P.L. and Oliveira, M. E. 2010. Changes in soil microbial biomass and activity in different Brazilian pastures. Spanish J. Agri. Res., 8: 12531259.

Mbagwu, J.S.C. 1991. Mulching an ultisol in south eastern Nigeria: effects on physical properties and maize and cowpea yields. J. Sci. Food and Agriculture, 57: 517526.

Nath, D. J., Ozah, B., Baruah, R., Barooah, R. C. and Borah, D. K. 2011. Effect of integrated nutrient management on soil enzymes, microbial biomass carbon and bacterial populations under rice (Oryza sativa)-wheat (Triticum aestivum. sequence. The Indian J. Agri. Sci., 81(12).

Page, A.L. 1982. Methods of soil analysis: chemical and microbiological properties. Amen Society of Agronomy.

Sharma, V.K., Pandey, R. N., Kumar, S., Chobhe, K.A. and Chandra, S. 2016. Soil test crop response based fertilizer recommendations under integrated nutrient management for higher productivity of pearl millet (Pennisetum glaucum L.. - wheat (Triticum aestivum L). under long term experiment. Indian J. Agri. Sci., 86: 1076-81.

Sharma, V.K., Pandey, R.N. and Sharma B.M. 2015. Studies on longterm impact of STCR based integrated fertilizer use on pearlmillet (Pennisetum glaucum L.)wheat (Triticum aestivum L). cropping system in semi-arid condition of India. $J$. Environ. Biol., 36: 241-247.

Singh, N.K. and Dhar, D.W. 2011. Microalgae as second generation biofuel. A review. Agronomy for Sustainable Development, 31: 605-629.

Yang, Y., Wu, L., Lin, Q., Yuan, M., Xu, D., $\mathrm{Yu}, \mathrm{H}$. and Xue, K. 2013. Responses of the functional structure of soil microbial community to livestock grazing in the Tibetan alpine grassland. Global Change Biol., 19: 637-648.

\section{How to cite this article:}

Chiranjeev Kumawat, V. K. Sharma, M. C. Meena, Sarvendra Kumar, Mandira Barman, Kapil A. Chobhe and Yadav R.K.. 2017. Fluorescein Diacetate activity as affected by residue retention and P fertilization in maize under maize-wheat cropping system. Int.J.Curr.Microbiol.App.Sci. 6(5): 2571-2577. doi: https://doi.org/10.20546/ijcmas.2017.605.289 